\title{
PERANCANGAN EFEKTIVITAS DAN EFISIENSI UNTUK PENINGKATAN PRODUKTIVITAS LINI PRODUKSI WELLHEAD DENGAN METODE OBJECTIVE MATRIX
}

\author{
Sudiman, Wakhit Ahmad Fahrudin* \\ Program Studi Teknik Industri, Fakultas Teknik, Universitas Pamulang \\ Email: 01307@unpam.ac.id; 01310@unpam.ac.id
}

Artikel masuk : 24-09-2020

Artikel direvisi : 05-01-2021

Artikel diterima : 11-01-2021

*Penulis Korespondensi

\begin{abstract}
Abstrak -- PT. Mulia Graha Abadi merupakan perusahaan manufaktur yang bergerak di bidang minyak dan gas bumi, yang mensuplai dan mengontrak peralatan pengeboran dengan tiga anak perusahaan. Dalam lima tahun terakhir, perusahaan belum mempunyai sistem pengukuran produktivitas terutama pada lini produksi wellhead. Penelitian ini bertujuan untuk menganalisis produktivitas lini produksi dengan menentukan indikator rasio yang dapat diukur sesuai kebutuhan untuk menghasilkan desain yang efektif dan efisien untuk tahun berikutnya. Penelitian ini menggunakan metode matriks objektif (OMAX) dengan perbandingan data kuantitas produksi, data kapasitas produksi, data tenaga kerja, data produk cacat, data produk yang dapat diperbaiki, data penggunaan bahan, data penggunaan energi, data mesin operasi, data total produksi. Berdasarkan hasil pengolahan data dan perhitungan angka indeks produktivitas menunjukkan bulan April 2019 yang mengalami penurunan sebesar $-41,18 \%$. Perancangan efektifitas dan efisiensi dengan perhitungan produktivitas dengan melakukan tindakan pengaturan kapasitas produksi secara simultan, memperhitungkan waktu yang digunakan untuk pengoperasian mesin sehingga dapat mencapai tingkat efektivitas sebesar 256 unit/bulan. Tingkat efisiensi dilihat dari faktor produksi atau kapasitas produksi masih terjadi penurunan sebesar 6,03\%. Desain yang efektif dan efisien memerlukan perencanaan yang terintegrasi dari semua departemen.
\end{abstract}

Kata kunci: Efektivitas; Efisiensi; OMAX; Produktivitas

\begin{abstract}
PT. Mulia Graha Abadi is a manufacturing company engaged in the oil and gas sector, which supplies and contracts drilling equipment with three subsidiaries. In the last five years, the company did not have a productivity measurement system, especially in the wellhead production line. This study aims to analyze the productivity of the production line by determining the ratio indicators that can be measured to produce an effective and efficient design for the following year. This study uses an objective matrix method (OMAX) to compare production quantity data, production capacity data, labor data, defect product data, repairable product data, material usage data, energy use data, operating machine data, total production data. The results of data processing and calculation of the productivity index figure show that April 2019 experienced a decrease of $-41.18 \%$. Designing effectiveness and efficiency by calculating productivity by taking action to control the production capacity simultaneously, taking into account the time spent operating the machine to achieve an effective 256 units/month level. The level of efficiency seen from the factor of production or production capacity still decreased by $6.03 \%$. Effective and efficient design requires integrated planning from all departments.
\end{abstract}

Keywords: Effectiveness; Efficiency; OMAX; Productivity

\section{PENDAHULUAN}

PT. Mulia Graha Abadi merupakan salah satu perusahan manufaktur yang bergerak dalam minyak dan gas dalam pemasok peralatan pengeboran maupun kontraktor dengan memiliki beberapa tiga anak perusahaan. Perusahaan dituntut dalam menghadapi perkembangan industri 4.0, mampu lebih produktif, inovatif dan mampu bersaing di dalam negeri maupun global.

Peningkatan produktivitas dapat digunakan sebagai penentuan target atau sasaran tujuan di dalam perusahaan (Ramayanti et al., 2020). 
Pokok dari permasalahan yang ada dalam perusahaan dapat disampaikan antara karyawan dengan manajemen secara periodik. Dengan adanya pengamatan dan perubahan-perubahan yang terjadi dalam setiap jam, hari, bulan dapat diperoleh data sebagai analisa tentang permasalahan yang ada di perusahaan (Gaspersz, 1998). Pada dasarnya perusahaan berupaya meningkatkan produktivitas dengan memperhatikan kegiatan efektivitas dan efisiensi.

Pengukuran produktivitas secara umum dapat dilihat dari berbagai tingkatan sesuai dengan tujuan yang ingin dicapai. Pertama adalah dengan membandingkan pelaksanaan secara data terdahulu tanpa mengevaluasi apakah kegiatan sekarang yang dilakukan efektif dan efisien. Yang kedua dengan membandingkan antara kelompok satu dengan kelompok lainya, mesin satu dengan mesin lainnya (Pristianingrum, 2017). Dalam hal ini merupakan pengukuran berdasarkan pencapaian relatif. Pengukuran produktivitas yang ketiga adalah membandingkan antara pelaksanaan kegiatan sekarang dengan kebijakan target yang harus dicapai. Pengukuran yang ketiga inilah yang dapat menentukan sebagai sasaran maupun tujuan (Wahyuni \& Setiawan, 2017).

Dalam studi lapangan bahwa lima tahun terakhir produksi wellhead di PT. Mulia Graha Abadi mengalami penurunan produksi paling rendah dengan hasil produksi pada tahun 2015 dan tertinggi pada tahun 2019 (Tabel 1). Selama rentang 5 tahun, perusahaan belum pernah mencapai target produksi yang telah ditetapkan perusahaan.

Tabel 1. Target dan Aktual Produksi

\begin{tabular}{lll}
\hline Tahun & $\begin{array}{l}\text { Target } \\
\text { Produksi }\end{array}$ & $\begin{array}{l}\text { Aktual } \\
\text { Produksi }\end{array}$ \\
\hline 2015 & 2910 set & 2690 set \\
2016 & 2920 set & 2682 set \\
2017 & 3925 set & 2680 set \\
2018 & 3930 set & 2679 set \\
2019 & 3935 set & 2628 set \\
\hline
\end{tabular}

Penentuan pengukuran produktivitas di perusahaan berguna sebagai alat ukur manajemen dalam menilai dan mengevaluasi tingkat efisiensi dan efektifitas produksi. Hal yang dilakukan pertama kali adalah tentang kesadaran dari karyawan paling bawah sampai top manajemen tentang pentingnya peningkatan produktivitas. Produktivitas akan berhasil dilakukan jika dijalankan dengan kesadaran tanpa adanya paksaan maupun otoriter dari pemimpin perusahaan itu sendiri (Gaspersz, 1998).
Produktivitas sering dihubungkan dengan dua aspek yang dapat dikombinasikan untuk mengetahui seberapa tingkat produktivitasnya. Kedua aspek tersebut adalah efektivitas dan efisiensi. Kombinasi efektivitas dengan menentukan kegiatan dalam proses kemampuan mengelola sumberdaya yang mendukung kelancaran proses produksi. Sedangkan efisiensi merupakan kegiatan yang mengurangi pemborosan untuk mendapatkan hasil yang lebih maksimal dengan jumlah masukan yang minimum. Oleh karena itu produktivitas diperoleh dari kegiatan efektivitas dan efisiensi (Tamtomo, 2008).

Berdasarkan informasi yang diperoleh PT. MGA belum adanya pengukuran produktivitas secara keseluruhan. Penelitian ini bertujuan untuk mengetahui dan menentukan rasio-rasio dalam peningkatan produktivitas serta merancang efektivitas dan efisiensi yang sangat erat hubunganya dengan produktivitas. Penentuan rasio-rasio produktivitas diharapkan mampu memberikan improvement dalam meningkatkan produktivitas.

\section{METODE PENELITIAN}

Metode yang digunakan dalam penelitian ini adalah Objective Matrix. Metode ini digunakan untuk mengetahui kinerja dari beberapa rasiorasio yang dihitung dengan target yang ditetapkan. Langkah perhitungan OMAX adalah menentukan rasio kriteria, pengukuran nilai standar, penentuan skor terendah, penentuan nilai dan skor aktual dan penentuan indeks produktivitas (Fithri \& Firdaus, 2016; Supriyadi \& Suryadiredja, 2020).

Metode pengumpulan data dilakukan dengan cara observasi dan kuesioner. Observasi dilakukan dengan cara melakukan pengamatan langsung di lingkungan PT. MGA dan melakukan observasi ketiga anak perusahaan untuk mendapatkan data-data yang akurat dan mencari metode yang tepat dalam penyelesaian masalah. Kuesioner dilakukan dengan cara mengajukan daftar pertanyaan yang secara langsung diberikan kepada responden dengan tujuan mendapatkan data yang dibutuhkan (Sugiyono, 2011). Penelitian menggunakan simple random sample dengan pihak-pihak yang terkait pada lini produksi wellhead maupun yang berkepentingan dari level manajer, supervisor dan operator.

Hasil pengumpulan data kemudian diolah untuk mencari solusi dari permasalahan yang dihadapi di lini produksi wellhead PT. MGA group. Pengolahan data terdiri atas beberapa tahap yaitu:

1. Memilih kriteria variabel indikator produktivitas yang paling berpengaruh di lini produksi dengan memberikan kuesioner dengan skala likert (Tabel 2) kepada pakar (expert 
judgement) (Agustina \& Riana, 2011). Hasil kuesioner sebagai dasar dalam nilai pembobotan pada langkah berikutnya.

Tabel 2. Skala Likert

\begin{tabular}{cl}
\hline Skala & \multicolumn{1}{c}{ Keterangan } \\
\hline 1. & Tidak penting \\
2. & Penting \\
3. & Keadaan dapat penting dan \\
& tidak penting \\
4. & Sangat penting \\
\hline
\end{tabular}

2. Menghitung tingkat produktivitas setiap kriteria produktivitas dengan (OMAX) dengan cara menentukan nilai awal dengan rata-rata level 3 , dimana $\mu$ adalah rata-rata rasio tiap kriteria yang diukur, $\mathrm{n}=$ jumlah data, dan $\mathrm{xi}=$ rasiorasio tiap kriteria

$\mu=\frac{\sum_{i=1 \times i} n}{n}$

3. Menentukan performansi standar dan skala level dengan skala interval (1-2) dan (4-9). Skala interval merupakan tingkat pencapaian antara (Intermediate) sebagai berikut: Interval $(1-2)=$ Level 3-Level $0(3-0)$. Interval $(4-9)$ $=$ Level 10-Level 3 (10-3)

4. Menghitung Indeks Produktivitas (IP) yang merupakan indikasi perubahan produktivitas yang terjadi pada perusahaan, dimana current merupakan nilai kriteria saat pengukuran, dan previous adalah nilai kriteria periode sebelumnya

Nilai IP $=\frac{\text { Current-Previous }}{\text { Previous }} \times 100 \%$

5. Merancang efektivitas dan efisiensi dengan menggunakan analisis waktu baku dalam hasil rasio yang menyebabkan produktivitas mengalami penurunan (Ramadhani et al., 2020).

\section{HASIL DAN PEMBAHASAN}

Hasil dari observasi di PT. MGA pada lini produksi wellhead dalam memproduksi berbagai spesifikasi produk (Tabel 3). Penentuan kriteria indikator rasio produktivitas berdasarkan hasil wawancara dan kuesioner dengan responden level manajer, supervisor, dan operator pada PT. MGA yang terlibat langsung pada lini produksi. Penentuan Rasio dapat dilihat bahwa variabel dalam produktivitas terdapat beberapa rasio yaitu efektivitas terdapat 3 rasio, efisien didapat 2 rasio dan kualitas didapat 2 rasio (Tabel 4). Data yang dibutuhkan adalah data kuantitas hasil produksi, data kapasitas produksi, data tenaga kerja, data produk cacat, data produk yang dapat diperbaiki, data penggunaan material, data penggunaan energi, data mesin beroperasi, data jumlah mesin
(Tabel 5).

Tabel 3. Komponen Produk Wellhead

\begin{tabular}{|c|c|c|}
\hline No & Dekripsi & Qty \\
\hline 1 & $\begin{array}{l}\text { Casing Head, } 13 \text { 5/8"-3M Flange Top X 13- } \\
\text { 3/8" SOW }\end{array}$ & 1 \\
\hline 2 & $\begin{array}{l}\text { Studbolts, 7/8" Dia x 6-1/4" Lg, ASTM A193 } \\
\text { GR, B7 }\end{array}$ & 8 \\
\hline 3 & API Ring gasket, R-24, 316 SS & 3 \\
\hline 4 & Gate Valve, 2-1/16"-3M Flange End & 1 \\
\hline 5 & Companion Flange, 2-1/16" -3M x 2LP & 2 \\
\hline 6 & Bull Plug, 2"LP X 4" Lg W 1/2" LP & 1 \\
\hline 7 & $\begin{array}{l}\text { Needle valve, M X F Angle, 1/2 NPT, 3M, } \\
\text { SS }\end{array}$ & 1 \\
\hline 8 & $\begin{array}{l}\text { Casing hanger Weight Set Slip 13-5/8 x 9- } \\
5 / 8 \text { " Casing }\end{array}$ & 1 \\
\hline 9 & $\begin{array}{l}\text { Studbolts, 7/8" Dia x 10-3/4" Lg, ASTM } \\
\text { A193 GR, B7 }\end{array}$ & 20 \\
\hline 10 & $\begin{array}{l}\text { Casing Spool, 13-5/8"-3M Flange Bottom X } \\
11 " 5 \mathrm{M}-\left(2 \_2-1 / 16 "-5 \mathrm{M} \text { TWO }\right.\end{array}$ & 1 \\
\hline 11 & Gate Valve, 2-1/16"-5M X 2"LP & 2 \\
\hline 12 & Companion Flange, 2-1/16" -5M x 2LP & 2 \\
\hline 13 & Bull plug, 2" LP X 4" LG W 1/2 NPT & 1 \\
\hline 14 & Needle valve, M X F Angle 1/2 NPT 5 M SS & 1 \\
\hline 15 & $\begin{array}{l}\text { Casing Hanger Weight Set Slip 11" x } 7 \\
\text { Casing }\end{array}$ & 1 \\
\hline 16 & API Ring gasket, R-54, 316 SS & 1 \\
\hline 17 & $\begin{array}{l}\text { Tubing Spool 11"-5M Flange Bottom X 7- } \\
\text { 1/16-5M Flange top }\end{array}$ & 1 \\
\hline 18 & Gate Valve, 2-1/16-5M Flange End & 2 \\
\hline 19 & Companion Flange, 2-1/16-5M 2"LP & 2 \\
\hline 20 & Bull Plug 2" LP X 4" LG W 1/2" NPT & 1 \\
\hline 21 & Needle Valve M X F Angle 1/2" NPT 5M SS & 1 \\
\hline 22 & $\begin{array}{l}\text { Extended Neck Tbg Hgr 7-1/16" X 3- } \\
\text { 1/2EUE Top \& Bottom 3" BPV H type }\end{array}$ & 1 \\
\hline 23 & $\begin{array}{l}\text { Tubing Head Adapter, 7-1/16"-5M Flange } \\
\text { Top Bottom X 3-1/8-5M Stdd Top }\end{array}$ & 1 \\
\hline
\end{tabular}

Tabel 4. Hasil Penentuan Rasio

\begin{tabular}{|c|c|c|c|}
\hline Variabel & $\begin{array}{c}\text { Rasio } \\
\text { Produktivitas }\end{array}$ & $\begin{array}{l}\text { Rata- } \\
\text { Rata }\end{array}$ & Bobot \\
\hline \multirow[t]{2}{*}{ Efektivitas } & $\frac{\text { Kuantitas Produksi Aktual }}{\text { Kapasitas produksi }}$ & 4,21 & 16,70 \\
\hline & $\frac{\text { Kuantitas Jam Kerusakan Me: }}{\text { Kuantitas Mesin Beroperasi }}$ & 4,34 & 15,61 \\
\hline \multirow{5}{*}{ Efisiensi } & Kuantitas Produksi & & \\
\hline & $\overline{\text { Kuantitas Penggunaan Mater }}$ & 3,23 & 15,82 \\
\hline & Kuantitas Produksi & \multirow[b]{2}{*}{3,11} & \multirow[b]{2}{*}{15,20} \\
\hline & $\overline{\text { Kuantitas Penggunaan Energ }}$ & & \\
\hline & $\frac{\text { Kuantitas Produksi }}{\text { Kuantitas Tenaga Kerja }}$ & 2,14 & 13,23 \\
\hline \multirow{2}{*}{ Kualitas } & $\frac{\text { Kuantitas Produk Cacat }}{\text { Kuantitas Produksi }}$ & 2,15 & 13,11 \\
\hline & $\frac{\text { Kuantitas Prduk dapat diperbai }}{\text { Kuantitas Produksi reject }}$ & 1,15 & 10,33 \\
\hline
\end{tabular}


Tabel 5. Data Aktual

\begin{tabular}{lccccccccc}
\hline \multicolumn{1}{c}{ Bulan } & $\begin{array}{c}\text { Data Hasil } \\
\text { Produks }\end{array}$ & $\begin{array}{c}\text { Kam } \\
\text { Kerja }\end{array}$ & $\begin{array}{c}\text { Produk } \\
\text { Cacat }\end{array}$ & $\begin{array}{c}\text { Tenaga } \\
\text { Kerja }\end{array}$ & $\begin{array}{c}\text { Produk } \\
\text { dapat } \\
\text { diperbaiki }\end{array}$ & $\begin{array}{c}\text { Penggunaan } \\
\text { Material }\end{array}$ & $\begin{array}{c}\text { Pemakaian } \\
\text { Energi }\end{array}$ & $\begin{array}{c}\text { Kerusakan } \\
\text { Mesin }\end{array}$ & $\begin{array}{c}\text { Mesin } \\
\text { Beroperasi }\end{array}$ \\
\hline Januari & (unit) & (unit) & (unit) & (jam) & (unit) & (pcs) & (Rp) & (jam) & (jam) \\
Februari & 238 & 206 & 4 & 40 & 3 & 87 & 20.350 .000 & 1,85 & 109,08 \\
Maret & 226 & 187 & 5 & 38 & 2 & 90 & 18.550 .000 & 1,08 & 99,62 \\
April & 230 & 197 & 3 & 39 & 3 & 95 & 19.530 .000 & 1,31 & 104,77 \\
Mei & 201 & 201 & 7 & 39 & 2 & 97 & 20.015 .000 & 1,7 & 106,54 \\
Juni & 241 & 204 & 5 & 40 & 1 & 92 & 20.130 .000 & 1,15 & 108,7 \\
Juli & 125 & 209 & 7 & 38 & 2 & 91 & 20.760 .000 & 0,62 & 111,31 \\
Agustus & 125 & 148 & 2 & 40 & 3 & 92 & 16.530 .000 & 0,92 & 79,07 \\
September & 245 & 209 & 11 & 40 & 2 & 95 & 2.057 .000 & 1,23 & 111,62 \\
Oktober & 271 & 212 & 8 & 35 & 3 & 98 & 21.030 .000 & 1,46 & 112,69 \\
Nopember & 242 & 205 & 11 & 37 & 4 & 95 & 20.250 .000 & 0,62 & 109,78 \\
Desember & 254 & 205 & 5 & 40 & 1 & 96 & 20.150 .000 & 0,85 & 109,46 \\
\hline
\end{tabular}

Tabel 6. Target Produktivitas Perusahaan

\begin{tabular}{|c|c|c|c|c|c|c|}
\hline & Rasio 1 & Rasio 2 & Rasio 3 & Rasio 4 & Rasio 5 & Rasio 6 \\
\hline $\begin{array}{c}\text { Kriteria } \\
\text { Produktivitas }\end{array}$ & $\begin{array}{c}\text { Jam Kerja } \\
\text { (pcs/org) }\end{array}$ & $\begin{array}{c}\text { Tenaga } \\
\text { Kerja } \\
\text { (pcs/org) }\end{array}$ & $\begin{array}{l}\text { Pemakaian } \\
\text { listrik (\%) }\end{array}$ & $\begin{array}{c}\text { Kualitas } \\
\text { Produk } \\
\text { Cacat(\%) }\end{array}$ & $\begin{array}{l}\text { Kerusakan } \\
\text { Mesin (\%) }\end{array}$ & $\begin{array}{c}\text { Lembur } \\
(\%)\end{array}$ \\
\hline \multirow{2}{*}{ Target } & Naik 30\% & Naik 30\% & Turun $30 \%$ & Turun $30 \%$ & Turun $30 \%$ & Turun $30 \%$ \\
\hline & 1.518 & 7.388 & 0,00143 & 3,65 & 1,48 & 23,39 \\
\hline
\end{tabular}

Target yang ditentukan oleh perusahaan dengan nilai yang akan dicapai oleh perusahaan, dipilih pada skor 10. Hasil ini didapat dengan hasil wawancara manajemen representatif pada perusahaan untuk menentukan ketercapaian yang diinginkan sehingga target peningkatan produktivitas dapat diperoleh pada jam kerja pada rasio 1 naik $30 \%$ yaitu 1,518 , rasio 2 tenaga kerja naik $30 \%$ yaitu 7,388, rasio 3 pemakaian listrik turun 30 $\%$ yaitu 0,00143 , rasio 4 kualitas produk turun $30 \%$ yaitu 3,65 , rasio 5 kerusakan mesin turun $30 \%$ yaitu 1,48 dan rasio 6 lembur turun $30 \%$ yaitu 23,39 (Tabel 6). Dengan demikian persentase dari target produktivitas sebesar $30 \%$. Tahapan berikutnya adalah perhitungan OMAX untuk mengetahui pengukuran produktivitas data yang diambil adalah data pada tahun 2019. Berdasarkan rumus level yang digunakan dalam acuan adalah terdiri dari 3 level, yaitu:

1. Level $0=$ Nilai level 0 dihitung berdasarkan nilai terendah.

2. Level $3=$ Nilai level 3 ditentukan oleh berdasarkan standar terendah.

3. Level $10=$ Nilai level 10 ditentukan berdasarkan nilai sasaran (Setiowati, 2017) .

Dalam proses pengukuran produktivitas dengan metode Objective Matrix penelitian ini dilakukan dalam rentan waktu dari bulan Januari
2019 sampai pada bulan Desember 2019. Langkah-langkah dalam pembuatan tabel OMAX seperti berikut ini:

1. Nilai standar dimasukan ke dalam baris skor ketiga

2. Nilai target dimasukan pada baris skor kesepuluh.

3. Nilai terendah pada periode skor 0 dimasukan dari hasil pengamatan

4. Nilai yang dimasukan pada baris $1,2,3,4,5,6,7$ dan 9 dengan format linier maupun non linier

5. Pada Tabel OMAX dimasukan nilai aktual pada setiap satu periode rasio dalam baris nilai

6. Nilai aktual pada rasio dengan kolom score ditentukan terhadap skor aktual di tabel matrik melalui dengan menentukan nilai yang terdekat antara baris aktual setiap nilai rasio.

7. Nilai bobot setiap rasio ditentukan berdasarkan kuesioner pada baris tabel matrik

8. Skor aktual dengan bobot dikalikan sehingga mendapatkan nilai produktivitas (Gea, 2014) .

Penentuan produktivitas dilakukan dengan cara interpolasi, yaitu menentukan nilainilai yang tersisa ke dalam matriks. Nilai-nilai ini akan masuk ke baris $1,2,4,5,6,7,8,9$. Perhitungan pada skala ini untuk mendapatkan nilai skala pada interval (1-2) dan (4-9) sehingga didapat nilai indek produktivitas. Dimana skor 3 didapat dari 
nilai rata-rata rasio produktivitas tahun 2019, skor 10 didapat dari target yang telah ditetapkan perusahaan dan skor 0 didapat dari nilai minimal dari rasio produktivitas.

Nilai Selang $10 \mathrm{~s} / \mathrm{d} 3$

$=($ Nilai Skor $10-$ Nilai Skor 3)/7

$=(1,755-1,17) / 7=0,084$

Nilai Selang 3 s/d 0

$=($ Nilai Skor 3-Nilai Skor 0$) / 3$

$=(1,17-0,84) / 3=0,11$

Nilai produktivitas $=$ Skor aktual $\times$ Bobot

$$
=3 \times 19.44=58,32
$$

Nilai produktivitas bulan januari berdasarkan hitungan produktivitas sebesar 340,91 (Tabel 7). Tingkat produktivitas terbaik terjadi pada bulan
Desember yaitu sebesar 433.96. Sedangkan untuk produktivitas terburuk terjadi pada bulan April yaitu sebesar 249.66. Kenaikan produktivitas pada bulan Desember disebabkan karena ada empat rasio produktivitas yang pencapaiannya diatas rata-rata, yaitu rasio jam kerja (skor 5), rasio tenaga kerja (skor 4), rasio produk cacat (skor 8), dan rasio jam lembur (skor 9) Jika dilihat berdasarkan produktivitas periode sebelumnya terdapat perubahan nilai indek produktivitas yaitu dengan nilai 44,55\% pada bulan Juli 2019 dan dapat dilihat dari bulan Agustus mulai meningkat. Namun pada bulan April 2019 mengalami penurunan produktivitas yang paling rendah yaitu $-41,18 \%$ (Tabel 8).

Tabel 7. Produktivitas Bulan Januari

\begin{tabular}{lccccccc}
\hline \multicolumn{1}{c}{ Rasio-Rasio } & $\begin{array}{c}\text { Kam } \\
\text { Kerja }\end{array}$ & $\begin{array}{c}\text { Tenaga } \\
\text { Kerja }\end{array}$ & $\begin{array}{c}\text { Pemakaian } \\
\text { Listrik }\end{array}$ & $\begin{array}{c}\text { Produk } \\
\text { Cacat }\end{array}$ & $\begin{array}{c}\text { Kerusakan } \\
\text { Mesin }\end{array}$ & $\begin{array}{c}\text { Jam } \\
\text { Lembur }\end{array}$ & Skor \\
\hline Nilai Aktual & 1,16 & 5,95 & 0,0012 & 1,7 & 1,7 & 17,04 \\
Target & 1,755 & 10,064 & 0,00042 & 1,12 & 0,42 & 4,375 & $\mathbf{1 0}$ \\
& 1,674 & 9,426 & 0,000518 & 1,36 & 0,504 & 6,32 & $\mathbf{9}$ \\
& 1,59 & 7,785 & 0,000615 & 1,6 & 0,61 & 8,19 & $\mathbf{8}$ \\
& 1,506 & 8,144 & 0,000712 & 1,84 & 0,716 & 10,06 & $\mathbf{7}$ \\
& 1,422 & 7,503 & 0,000809 & 2,08 & 0,822 & 11,93 & $\mathbf{6}$ \\
& 1,338 & 6,862 & 0,000906 & 2,32 & 0,928 & 13,8 & $\mathbf{5}$ \\
& 1,254 & 6,221 & 0,001003 & 2,56 & 1,034 & 15,67 & $\mathbf{4}$ \\
& 1,17 & 5,58 & 0,0011 & 2,81 & 1,14 & 17,99 & $\mathbf{3}$ \\
& 1,06 & 4,764 & 0,001197 & 3,57 & 1,327 & 21,16 & $\mathbf{2}$ \\
& 0,95 & 3,947 & 0,0001294 & 4,33 & 1,514 & 24,33 & $\mathbf{1}$ \\
& 0,84 & 3,13 & 0,0014 & 5,1 & 1,7 & 27,5 & $\mathbf{0}$ \\
\hline Skor Aktual & 3 & 3 & 3 & 8 & 0 & 3 & \\
Bobot & 19,44 & 19,1 & 17,02 & 17,35 & 15,27 & 11,81 & $\mathbf{3 5 , 4 3}$ \\
Nilai Produktivitas & $\mathbf{5 8 , 3 2}$ & $\mathbf{5 7 , 3}$ & $\mathbf{5 1 , 0 6}$ & $\mathbf{1 3 8 , 8}$ & $\mathbf{0}$ & & \\
\hline
\end{tabular}

Tabel 8. Nilai Produktivitas Tahun 2019

\begin{tabular}{lcc}
\hline Bulan & $\begin{array}{c}\text { Overall Productivity } \\
\text { (Opi) } \\
\text { (Opi) }\end{array}$ & $\begin{array}{c}\text { Nilai Indeks Perubahan terhadap } \\
\text { Produktivitas }\end{array}$ \\
\hline Januari & 340,91 & 0 \\
Februari & 365,92 & 7,34 \\
Maret & 424,43 & 15,99 \\
April & 249,66 & $-41,18$ \\
Mei & 316,25 & 26,67 \\
Juni & 273,3 & $-13,58$ \\
Juli & 395,05 & 44,55 \\
Agustus & 332,25 & $-15,9$ \\
September & 303,78 & $-8,57$ \\
Oktober & 314,87 & 3,65 \\
November & 356,89 & 13,35 \\
Desember & 433,96 & 21,59 \\
\hline
\end{tabular}


Dalam memperoleh skor 10 maka digunakan dengan nilai indek produktivitas melalui penjumlahan berdasarkan nilai produktivitas dari semua rasio terhadap keenam rasio yang digunakan (Nofirza et al., 2012). Nilai Indeks Produktivitas = Jam Kerja + Jam Lembur + Kerusakan Mesin + Produk Cacat + Pemakaian Listrik + Tenaga Kerja $=58.32+35.43+0+138.8$ $+51.06+57.3=340,91$. Dari hasil pengolahan data yang dilakukan, dapat diketahui indeks produktivitas pada periode pengukuran setiap bulannya.

$$
\begin{aligned}
I P & =\frac{I P \text { Sekarang }-I P \text { Sebelumnya }}{I P \text { Sebelumnya }} \times 100 \% \\
I P & =\frac{251,04-282,95}{282,95} \times 100 \% \\
& =-11,28 \%
\end{aligned}
$$

Nilai indeks perubahan terhadap produktivitas periode sebelumnya dapat diketahui bahwa nilai terbesar terjadi pada bulan Juli 2019 yang yaitu sebesar $44.55 \%$ yang merupakan peningkatan terbesar dari bulan Agustus. Sedangkan untuk penurunan produktivitas terburuk terjadi pada bulan April 2019 yaitu sebesar -41.18\% (Gambar 1). Kriteria pada bobot masing-masing melalui perkalian setiap kriteria merupakan produktivitas total atau dapat disebut dengan produktivitas keseluruhan dari kriteria. Perubahan produktivitas terjadi karena fluktuasi dari naik dan turunnya beberapa faktor yang dapat mempengaruhinya.(Nurdin \& Zabidi, 2005).

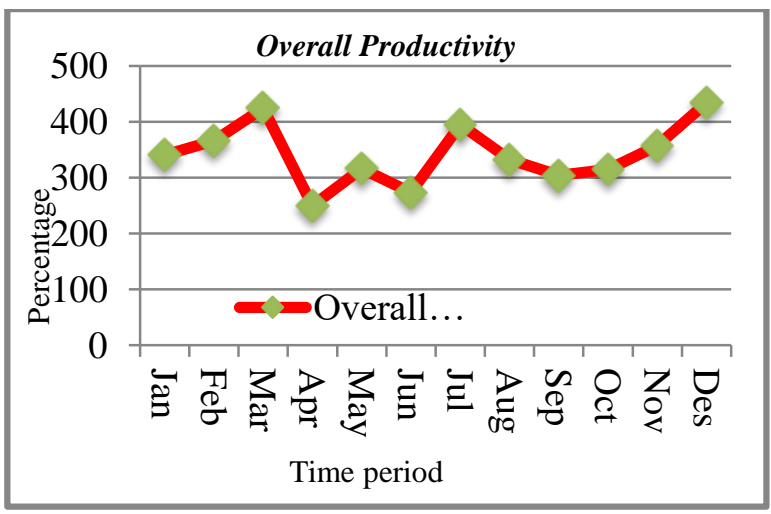

Gambar 1. Produktivitas Total

Pada hasil perhitungan dengan meng gunakan OMAX diketahui bahwa indikator efektivitas terdapat pada rasio 1 menunjukan nilai yang masih dalam kondisi baik produktivitasnya tetapi pada rasio 2 yang dapat dikatakan bahwa dalam indikator ini menunjukan penyebab bahwa indikator turunya produktivitas yaitu pada sering terjadinya kerusakan pada mesin sehingga mengakibatkan proses produksi menjadi terganggu karena down time.
Rancangan sebelumnya bahwa efektif didapat berdasarkan jam penggunaan mesin dibagi dengan target produktivitas. Untuk usulan rancangan diukur berdasarkan rasio output aktual terhadap output yang direncanakan, sehingga dalam mencapai produktivitas lebih terukur. Untuk rancangan efisiensi diketahui bahwa rancangan sebelumnya hanya dengan memperhitungkan dalam segi penghematan pemakaian bahan baku, tenaga listrik, tenaga kerja. Rancangan dalam efisiensi hasil penelitian ini dengan memperhatikan pada hasil output sebuah produk terhadap pemakaian fasiliti pendukung dalam proses produksi (Fahrudin, 2018).

\section{Jam kerja $x$ minggu kerja efektif $x$ jumlah output}

Berdasarkan data yang dikumpulkan perusahaan pada tahun 2019 dapat dihitung dalam satu jam jumlah yang dihasilkan pada mesin dalam memproduksi lockdown screw diambil contoh pada bulan januari sebesar 238 unit/jam, maka untuk kapasitas keefektivitasan adalah:

$\mathrm{KE}=8 \mathrm{jam} \times 16 \times 2$ unit/hari

$$
=256 \text { unit/bulan }
$$

Jumlah output dalam keefektivitasan hasil produksi 238 unit/bulan yang idealnya dalam efektifitasnya dengan jumlah 256 unit/bulan. Berdasarkan waktu baku dalam perusahaan adalah dengan membandingkan jumlah pemakaian mesin dibagi dengan jumlah output hasil produksinya dengan kapasitas mesin menghasilkan 256 unit/bulan.

$$
\begin{aligned}
\text { Efisiensi } & =\frac{\text { Hasil Produksi } / \mathrm{jam}}{\text { Kapasitas Mesin } / \text { Unit }} \times 100 \% \\
\text { Efisiensi } & =\frac{238}{256} \times 100 \% \\
& =92,97 \%
\end{aligned}
$$

Rancangan efisiensi pada contoh bulan Januari sebesar $92,97 \%$. Hasil penelitian ini membuktikan bahwa terdapat rasio-rasio yang dapat mempengaruhi produktivitas dan diantaranya adalah rasio jam kerja, jam kerja yang optimal dan mengurangi lembur cenderung meningkatkan produktivitas pada lini produksi wellhead. Begitu juga rasio tenaga kerja, faktor ini dipengaruhi adanya jumlah tenaga kerja dengan jumlah produk yang dihasilkan serta rasio pada produk cacat.

\section{KESIMPULAN}

Berdasarkan hasil pengolahan data dengan menggunakan metode objective matrix didapatkan empat rasio dengan nilai produktivitas pencapaian diatas rata-rata, yaitu rasio jam kerja (skor 5), rasio tenaga kerja (skor 4), rasio produk 
cacat (skor 8), dan rasio jam lembur (skor 9) sehingga pada rasio ini diharapkan dapat dipertahankan. Sedangkan untuk indek produktivitas rasio yang paling berperan dalam menurunnya indek produktivitas adalah rasio produktivitas produk cacat dengan nilai signifikan dari 156.35 menjadi 34.7. Rancangan efektivitas perhitungan rasio produktivitas dengan melakukan tindakan pada pengaturan kapasitas produksi sebesar 256 unit/bulan. Tingkat efisiensi dilihat dari faktor hasil produksi aktual dengan kapasitas produksi masih terjadi penurunan sebesar $6,03 \%$. Untuk itu dengan melakukan tindakan menjaga preventive maintenance dengan perawatan rutin dan terjadwalkan mampu mengurangi kerusakan secara tiba tiba yang mengganggu kelancaran proses produksi wellhead. Penelitian selanjutnya disarankan untuk meneliti bagian maintenance baik mesin maupun peralatan yang digunakan pada lini produksi wellhead.

\section{UCAPAN TERIMAKASIH}

Dalam penelitian ini yang pertama kami mengucapkan terimakasih kepada Direktorat Riset dan Pengabdian Kepada Masyarakat, Direktorat Jenderal Penguatan Riset dan Pengembangan, Kementerian Riset dan Teknologi/Kementerian Ristek BRIN yang telah menghibahkan dana pada penelitian ini dengan nomor kontrak: 0156/D5 /KP/LPPM /UNPAM/IV/2020. Yang kedua ucapan terimakasih kepada PT. MGA beserta seluruh jajaranya yang bersedia memfasilitasi penelitian ini sehingga penelitian ini berjalan dengan baik.

\section{DAFTAR PUSTAKA}

Agustina, F., \& Riana, N. A. (2011). Analisis Produktivitas dengan Metode Objective Matrix (OMAX) di PT. X. Teknik Dan Manajemen Industri, 6(2), 150-158. https://journal.trunojoyo.ac.id/jtmi/article/vie w/32

Fahrudin, W. A. (2018). Analisis Keevektifitasan Mesin Bubut Konvensional Sebagai Usulan Perbaikan dalam Penerapan Total Productive Maintenance di PT. Xintai Indonesia. JITMI (Jurnal IImiah Teknik dan Manajemen Industri), 1(2), 180-188. http://openjournal.unpam.ac.id/index.php/JI TM/article/view/3132

Fithri, P., \& Firdaus, I. (2016). Analisis Produktifitas Menggunakan Metode Objective Matrix (OMAX) (Studi Kasus: PT. Moradon Berlian Sakti). Jurnal Optimasi Sistem Industri, 13(1), 548-555. https://doi.org/10.25077/josi.v13.n1.p548555.2014

Gaspersz, V. (1998). Manajemen Produktivitas
Total. Jakarta: Gramedia Pustaka Utama.

Gea, A. A. (2014). Time Management: Menggunakan Waktu Secara Efektif dan Efisien. Humaniora, 5(2), 777-785. https://doi.org/10.21512/humaniora.v5i2.313 3

Nofirza, N., Syahputra, D., Rochman, T., Astuti, R. D., Patriansyah, R., Kristanto, A., Widodo, S. C., \& Manopo, R. (2012). Perancangan alat pemotong nenas yang ergonomis untuk meningkatkan produktivitas. Jurnal IImiah Teknik Industri, 11(1), 41-50. http://journals.ums.ac.id/index.php/jiti/article /view/1122

Nurdin, R., \& Zabidi, Y. (2005). Pengukuran Dan Analisis Produktivitas Lini Produksi PT. XYZ Dengan Menggunakan Metode Objective Matrix. Dalam Jurnal Teknik Industri Sekolah Tinggi Teknologi Adisujipto (STTA). Yogyakarta, 1-10. http://www.stta.ac.id/jurnal/omaxsinarsemes ta.pdf

Pristianingrum, N. (2017). Peningkatan efisiensi dan produktivitas perusahaan manufaktur dengan sistem Just In Time. ASSETS: Jurnal IImiah IImu Akuntansi, Keuangan Dan Pajak, 1, 41-53. http://ejournal.stiewidyagamalumajang.ac.id /index.php/asset/article/view/20

Ramadhani, M. R., Rezekiah, A. A., \& Pitri, R. M. N. (2020). Karakteristik Pengrajin dan Produktivitas Kerajinan Rotan di Kecamatan Haur Gading Kabupaten Hulu Sungai Utara Provinsi Kalimantan Selatan. Jurnal Sylva Scienteae, 3(2), 394-402. https://ppjp.ulm.ac.id/journals/index.php/jss/ article/view/1991

Ramayanti, G., Sastraguntara, G., \& Supriyadi, S. (2020). Analisis Produktivitas dengan Metode Objective Matrix (OMAX) di Lantai Produksi Perusahaan Botol Minuman. Jurnal INTECH Teknik Industri Universitas Serang Raya, 6(1), 31-38. https://doi.org/10.30656/intech.v6i1.2275

Setiowati, R. (2017). Analisis pengukuran produktivitas departemen produksi dengan metode Objective Matrix (OMAX) pada CV. Jaya Mandiri. Faktor Exacta, 10, 199-209. https://journal.Ippmunindra.ac.id/index.php/ Faktor_Exacta/article/view/1321

Sugiyono. (2011). Metodologi penelitian kuantitatif kualitatif dan R\&D. Bandung: Alfabeta.

Supriyadi, S., \& Suryadiredja, A. D. (2020). Pengukuran produktivitas lini produksi gula rafinasi dengan pendekatan Objective Matrix (OMAX). Operations Excellence: Journal of Applied Industrial Engineering, 12(2), 219227. 
https://doi.org/10.22441/oe.2020.v12.i2.008 Tamtomo, A. T. (2008). Pengukuran Produktivitas Proses Produksi PT. Halco Dengan Menggunakan Alat Ukur Omax (Objectives Matrix). Tesis. Jakarta: Universitas Indonesia.

http://lontar.ui.ac.id/file?file=pdf/abstrak120418.pdf
Wahyuni, H. C., \& Setiawan, S. (2017). Implementasi Metode Objective Matrix (OMAX) Untuk Pengukuran Produktivitas Pada PT.ABC. PROZIMA (Productivity, Optimization and Manufacturing System Engineering), 1(1), 17. https://doi.org/10.21070/prozima.v1i1.702 